\title{
KOMPETENSI PERAWAT DALAM MENGAMBIL KEPUTUSAN KEPERAWATAN
}

\author{
Cindy Minannisa
}

\section{cindyminannisa01@gmail.com}

\begin{abstract}
Abstrak
Penting bagi perawat untuk mampu mengambil keputusan dengan melibatkan pasien dan keluarga dalam asuhan keperawatannya sehingka proses keperawatan yang diberikan kepada klein ini diarahkan sebagai proses refleksi baik bagi perawat ataupun klien. Pengambilan keputusan adalah suatu proses penilaian dan pemilihan dari berbagai alternatif sesuai dengan kepentingan-kepentingan tertentu dengan menetapkan suatu pilihan yang dianggap paling menguntungkan (Machfoedz, 2005). Pengambilan keputusan terjadi melalui proses perilaku yang terdiri dari pengenalan masalah, mencari informasi, evaluasi terhadap alternative dan hasil dari pengambilan keputusan. Tujuan: untuk mengetahui bagaimana kompetensi perawat dalam mengambil keputusan terhadap pasien. Metode: Tugas ini menggunakan metode kualitatif dan analisis dari berbagai jurnal yang berhubungan dengan kompetensi dan peran perawat dalam mengambil keputusan dari proses keperawatan. Hasil: perawat mengetahui cara pengambilan keputusan yang baik dan memahami setiap langkah-langkah dari pengambilan keputusan dengan baik dan tepat.
\end{abstract}

\section{Kata Kunci: Pengambilan keputusan, Perawat}

\section{Latar Belakang}

Kompetensi perawat sangat banyak dalam melakukan tugasnya sebagai tenaga kesehatan yang professional. Menurut Potter and Perry (2005), bahwa perawat mempunyai fungsi yang sangat luas yang membutuhkan pengetahuan dan keterampilan dalam lingkup area yang bervariasi. Dalam melaksanakan fungsinya tersebut perawat melaksanakan peran-peran yang saling berhubungan seperti pemberi pelayanan keperawatan, pengambilan keputusan, protector dan advokat bagi pasien, manajer, rehabilitator, komunikator, comforter dan pendidik. Untuk berperan secara aktif dalam memenuhi kebutuhan pelayanan kesehatan, diperlukan perawat yang 
mampu berpikir krtis dan logis untuk mengambil keputusan yang tepat dalam memecahkan masalah.

Pengambilan keputusan adalah suatu pendekatan yang sistematis terhadap hakekat suatu masalah dengan pengumpulan fakta-fakta dan data, menentukan alternatif yang matang untuk mengambil suatu tindakan yang tepat. Pengambilan keputusan dalam penyelesaian masalah adalah kemampuan mendasar bagi praktisi kesehatan, khususnya dalam asuhan keperawatan dan kebidanan.

Nigro (dalam Ridho, 2003) mengemukakan bahwa keputusan ialah pilihan sadar dan teliti terhadap suatu alternatif yang memungkinkan dalam suatu posisi tertentu untuk merealisasikan tujuan yang diharapkan. Dalam Sumijatun(2011), dikatakan bahwa pembuatan keputusan selalu dihubungkan dengan suatu masalah atau suatu kesulitan, dalam arti keputusan dan penerapannya diharapkan akan menjawab persoalan atau menyelesaikan konflik. Pendapat Kepner dan George tentang pengambilan keputusan adalah "A decision is always choice between various ways of getting a particular thing done on end accomplished". Pengambilan keputusan adalah suatu rangkaian kegiatan memilih alternatif atau kemungkinan. Dalam pengambilan keputusan keperawatan melibatkan prinsip-prinsip etis sebagai bahan pertimbangan.

Kemampuan pengambilan keputusan yang tepat dan akurat sangat diperlukan bagi tenaga kesehatan khususnya para perawat untuk dapat menyelamatkan pasien yang dihadapi. Pola-pola perilaku pengambilan keputusan yang dilakukan oleh para tenaga kesehatan ini melibatkan aspek-aspek fisik maupun psikis yang sangat besar, mengandung resiko yang cukup tinggi antara keselamatan dan kematian dari pasien yang sedang dihadapi.

Pengambilan keputusan merupakan proses pemecahan masalah yang berfokus pada analisa situasi yang sulit untuk mengambil solusi yang memutuskan permasalah tersebut. Dalam pengambilan keputusan perawat harus mempertimbangkan segala aspek, baik dari pasien itu sendiri, keluarga pasien, tenaga kesehatan lain, psiko, sosial, dan cultural yang diterapkan. Perawat juga harus ikut membantu klien ataupun keluarga klien dalam mengambil keputusan yang berhubungan dengan kesehatan klien. Oleh karena itu Perawat juga sebagai seorang praktisi yang berpendidikan diharapkan mempunyai kemampuan intelektual untuk menggunakan 
pemikiran rasional dan refektif saat perawat mempertimbangkan pengamatan dan informasi tentang kondisi masing-masing pasien.

\section{Metode}

Metode ini menggunakan metode kualitatif analisis berlandaskan teori dari buku, jurnal, e-book ataupun sumber informasi lainnya yang memuat informasi dengan pembahasan pengambilan keputusan oleh perawat. Dengan metode ini informasi pembahasan mengenai kompetensi perawat dalam mengambil keputusan sebagai bagian dari proses keperawatan dapat dihami dan mempelajari bagaimana cara mengambil keputusan dengan tepat sesuai dengan langkah-langkah proses keperawatan dalam mengambil keputusan. Sumber yang digunakan bersifat subjektif yaitu proses penulisan yang lebih fokus pada landasan teori. Dan melakukan analisis buku dan e-jurnal yang relevan dan berfokus kepada pengaplikasian berfikir kritis dalam mengelola informasi dan komunikasi keperawatan. Sumber yang digunakan adalah sumber yang diterbitkan di 8 tahun terakhir dan referensi akan dicantumkan dibagian daftar pustaka.

\section{Hasil}

Perawat merupakan tenaga profesional yang bertanggung jawab dalam memberikan proses keperawatan kepada klien. Berdasarkan hal tersebut perawat harus mampu mengambil keputusan klinis sebagai upaya membantu pasien dalam memecahkan masalah dan menemukan jalan keluar dari setiap masalah keperawatan yang dialami klien selama masa penyembuhan ataupun konsultasi.

Pengambilan keputusan adalah pemilihan diantara alternatif-alternatif mengenai sesuatu cara bertindak dan inti dari perencanaan. Suatu rencana dapat dikatakan tidak ada, jika tidak ada keputusan suatu sumber yang dapat dipercaya, petunjuk atau reputasi yang telah dibuat (Laudon, 2008 : 148).

kemampuan perawat dalam pengambilan keputusan didasarkan pada keterampilan dan pengetahuan yang luas yang dimiliki oleh perawat. Pengetahuan dapat diwujudkan dengan berpikir kritis. Berpikir kritis dalam keperawatan adalah suatu keterampilan berpikir untuk menguji berbagai alasan secara rasional sebelum perawat mengambil keputusan dalam perawatannya. 
Pemikir yang kritis akan memperhatikan apa yang penting dalam sebuah situasi, membayangkan dan mengeksplorasi semua alternatife, mempertimbangkan kode etik, dan kemudian membuat suatu keputusan. Perawat yang menerapkan pemikiran kritis dalam bekerja akan focus terhadap penyelesaian masalah dan membuat keputusan, serta tidak akan membuat keputusan yang terburu-buru ataupun ceroboh (Kataoka-Yahiro dan Saylor, 1994).

Pengambilan keputusan dalam keluarga yang berimplikasi pada status kesehatan maternal ini juga dipengaruhi oleh beberapa faktor. Faktor tersebut meliputi: pendidikan, pengetahuan keluarga akan komplikasi yang dialami, status perempuan dalam keluarga, sosio ekonomi keluarga, kepemilikan asuransi kesehatan, dan budaya yang berpengaruh pada keluarga.

Perawat memiliki tanggung jawab dan kewenangan untuk mengambil langkah - langkah keperawatan yang diperlukan sesuai dengan standar keperawatan. Pelayanan keperawatan di Indonesia di masa depan diperkirakan juga akan menuju pelayanan atau asuhan keperawatan profesional yang bersifat holistik dan humanistik, berlandaskan ilmu dan kiat keperawatan dengan etika keperawatan sebagai tuntunan (Husin, 1995).

Perawat harus memiliki keterampilan dan ilmu pengetahuan dalam proses dasar pembuatan keputusan yaitu mengenali dan menentukan masalah keperawatan, melakukan pengumpulan data yang signifikan dengan mendapatkan informasi tersebut. Selanjutnya mengembangkan alternatif, mengevaluasi dampak positif dan negative dari alternative, kemudian memilih alternatif terbaik dengan dampak negative terkecil, perawat mengimplementasikan keputusan serta mengevaluasi adanya perubahan kesehatan yang dialami pasien akibat dari pengambilan keputusan tadi.

\section{Pembahasan}

Keperawatan merupakan salah suatu profesi pemberi asuhan kepada individu, keluarga, kelompok atau masyarakat baik dalam keadaan sakit maupun sehat. Salah satu indikator keberhasilan Rumah Sakit adalah kinerja tenaga keperawatan dalam memberikan pelayanan kesehatan yang baik sesuai dengan standar pelayanan keperawatan.

Perawat merupakan disiplin ilmu dan profesi yang humanis dan ilmiah, yang tujuan utamanya adalah untuk melayani individu, kelompok, komunitas, masyarakat dan institusi. 
Perawat juga sebagai seorang praktisi yang berpendidikan diharapkan mempunyai kemampuan intelektual untuk menggunakan pemikiran rasional dan refektif saat perawat mempertimbangkan pengamatan dan informasi tentang kondisi masing-masing pasien. Sepanjang komponen dari proses keperawatan, perawat menggunakan sikap dan kemampuan berfikir kritis untuk menentukan relevansi, makna dan iterrelasi data pasien serta untuk menetapkan asuhan keperawatan yang sesuai (Cristensen \& Kenney, 2009).

Pengambilan keputusan merupakan suatu pendekatan sistematis untuk menyelesaikan suatu masalah. Pengambilan keputusan dalam penyelesaian masalah membutuhkan kemampuan yang mendasar bagi praktisi kesehatan, khususnya dalam asuhan keperawatan (Dolan, 2017).

Pengambilan keputusan adalah pemilihan diantara alternatif-alternatif mengenai sesuatu cara bertindak dan inti dari perencanaan. Suatu rencana dapat dikatakan tidak ada, jika tidak ada keputusan suatu sumber yang dapat dipercaya, petunjuk atau reputasi yang telah dibuat (Laudon, 2008 : 148).

Proses pengambilan keputusan dalam praktik keperawatan dipahami sebagai serangkaian keputusan yang dibuat oleh perawat dalam interaksinya dengan pasien mengenai jenis pengamatan yang akan dilakukan dalam situasi yang di alami klien (pengkajian keperawatan), perumusan diagnosa keperawatan, rencana tindakan keperawatan yang harus diambil, tindakan keperawatan yang akan diambil serta evaluasi (Dianan Catarina. 2009, Jan Florin. 2007, Mehee, 2014).

Hariyati (2014) mengatakan bahwa dalam pengambilan keputusan yang tepat tentunya harus didasari dengan kemampuan seorang perawat dalam berfikir secara kritis. Perawat harus mampu mengidentifikasi masalah pasien dan memilih solusi intervensi yang tepat, karena perawat akan menghadapi bermacam- macam situasi klinis yang berhubungan dengan pasien dimana hal ini tak lepas dari kemampuan perawat dalam berfikir kritis, karena dengan berfikir secara kritis perawat dapat mengambil keputusan secara sitematis dan tepat dalam setiap tahapan asuhan keperawatan yang dilakukan.

Perawat memiliki tanggung jawab dan kewenangan untuk mengambil langkah - langkah keperawatan yang diperlukan sesuai dengan standar keperawatan. Pelayanan keperawatan di Indonesia di masa depan diperkirakan juga akan menuju pelayanan atau asuhan keperawatan 
profesional yang bersifat holistik dan humanistik, berlandaskan ilmu dan kiat keperawatan dengan etika keperawatan sebagai tuntunan (Husin, 1995).

Lahirnya keputusan tidak serta-merta berlangsung secara sederhana begitu saja, sebab senuah keputusan itu selalu saja lahir berdasarkan dari proses memakan waktu, tenaga dan pikiran sehingga akhirnya terjadi suatu pengkristalan dan lahirlah keputusan tersebut. Saat pengambilan keputusan adalah saat dimana kita sepenuhnya memilih kendali dalam bertindak. Selanjutnya yang dianggap penting adalah pertanggung jawaban dari keputusan itu sendiri kepada pihak yang berkepentingan (Fahmi, 2011:4).

Proses pengambilan keputusan dalam tindakan keperawatan merupakan komponen penting dalam proses keperawatan, sehingga dibutuhkan kemampuan perawatan karena keterbatasan pengetahuan dan kemampuan yang dimiliki perawat dapat menghambat perawat dalam mengambil keputusan mengenai perawatan yang akan diberikan kepada klien yang akan berakibat fatal terhadap klien. Penting bagi perawat untuk mampu mengambil keputusan dengan melibatkan pasien dan keluarga dalam asuhan keperawatannya sehingga proses keperawatan yang diberikan kepada klien ini diarahkan sebagai proses refleksi baik bagi perawat ataupun klien.

Proses atau elemen-elemen dalam pengambilan keputusan ada 7 yaitu:

1. Mendefinisikan Masalah

Untuk mengetahui hakekat suatu masalah tidaklah mudah, karena masalah yang sebenarnya dihadapi sering terselubung dan tidak terlihat jelas. Oleh karena itu diperlukan keahlian, pendidikan dan pengalaman untuk membuat diagnosa yang tepat. Untuk itu manajer perawat dan bidan agar selalu mengembangkan kemampuannya dan belajar dari pengalaman di masa lalu untuk mempelajari perubahan yang terjadi.

2. Pengumpulan Data

Pengumpulan data merupakan tahap awal dari proses pengkajian. Perawat harus mengumpulkan data yang bersifat deskriptif, singkat, dan lengkap. Data deskriptif berasal dari persepsi klien tentang gejala, persepsi dan pengamatan keluarga, pengamatan perawat, atau laporan dari anggota tim perawatan kesehatan. Pengumpulan data dilakukan setiap kali berinteraksi dengan klien, keluarga dan sumber data pendukung. Pengumpulan data dilakukan melalui dua tipe, yaitu: pengkajian dasar (pengkajian screening) dan pengkajian terfokus. 
Pengkajian dasar adalah pengkajian yang dilakukan ketika pertama kali klien masuk ke pelayanan kesehatan. Hal tersebut bertujuan untuk mengevaluasi status kesehatan dan mengidentifikasi fungsi pola kesehatan yang bermasalah (Gordon 1994; Craven dan Hirnle 2000).

\section{Analisa Fakta dan Data}

Fakta-fakta dan data yang telah terkumpul dengan baik diolah secara sistematis yang akhirnya akan merupakan suatu informasi yang akan digunakan sebagai bahan untuk pengambilan keputusan.

\section{Penentuan Alternatif}

Baik buruknya sesuatu keputusan yang diambil sangat tergantung atas kemampuan menganalisa kekuatan dan kelemahan alternatif-alternatif yang dihadapi. Jika batas batas keputusan telah didefinisikan dengan lebih sempit maka pilihan pilihan dengan sendirinya lebih mudah tersedia. Namun, jika keputusan yang diambil masih didefinisikan secara luas maka proses menetapkan pilihan merupakan proses kreatif.

\section{Penentuan Pilihan yang Terbaik}

Umumnya pilihan diambil dari beberapa alternatif jika diduga bahwa pilihan itu akan memberikan manfaat yang paling besar baik untuk jangka panjang maupun jangka pendek. Namun demkian perlu dipertimbang juga bahwa resiko yang menyertai bersifat moderat. Pada fase ini salah satu dari beberapa pilihan keputusan yang tersedia telah dipilih, dengan pertimbangan apabila diterapkan akan menjanjikan suatu kepuasan.

Pengambilan keputusan dalam penggunaan layanan kesehatan sangat dipengaruhi oleh pemahaman individu akan karakteristik penyakit itu sendiri. Proses dimulai dari mengenali kondisi abnormal yang terjadi, mengetahui seberapa parah, dan mengetahui penyebab dari adanya kelainan yang dirasakan oleh individu lalu memutuskan untuk mencari perawatan. Sebelum memutuskan untuk mendapatkan pengobatan, individu perlu mengenali kondisi yang dihadapi seiring dengan dibutuhkannya perhatian yang lebih terhadap kondisi tersebut. Mengenali kondisi kesehatan dapat juga dibentuk oleh persepsi dan interpretasi sosiokultural.

\section{Evaluasi}

Untuk mengadakan penilaian yang baik, diperlukan obyektivitas dalam melakukan penilaian atau evaluasi. Biasanya suatu hal yang sangat sukar bagi seseorang untuk menilai dirinya sendiri secara obyektif. Oleh karena itu pelaksanaan penilaian dapat diserahkan kepada 
pihak ketiga yang tidak terlibat langsung dalam proses pengambilan keputusan untuk memperoleh tingkat obyektivitas setinggi mungkin.

Pengambilan keputusan klinis akan memperlihatkan perbedaan antara perawat dengan staf teknis, yaitu perawat akan cepat bertindak ketika kondisi pasien menurun mendeteksi masalahnya dan berinisiatif untuk memperbaikinya. Benner (1984) berpendapat bahwa pengambilan keputusan klinis sebagai keputusan yang terdiri atas pemikiran kritis dan penuh pertimbangan, serta penetapan dari ilmu serta pikiran kritis. Klien tentu akan memiliki keluhan yang berbeda-beda yang dipengaruhi oleh kesehatan fisik, gaya hidup, budaya, hubungan kekerabatan, lingkungan tempat tinggal, hingga pengalaman klien itu sendiri. Oleh karena itu, perawat tidak bisa langsung mengetahui apa yang klien butuhkan, melainkan klien tersebut harus menyampaikan keluhan yang ia punya dan perawat harus banyak bertanya dan memiliki rasa ingin tahu untuk melihat suatu hal dengan perspektif yang berbeda.

Kemampuan para perawat dalam kondisi-kondisi kritis ketika menangani pasien tentu tidak lepas dari latar belakang pendidikan yang pernah ditempuh serta pengalaman yang pernah dijalani. Termasuk di sini adalah kemampuan perawat dalam mengambil keputusan saat gawat darurat. kemampuan perawat mengidentifikasi masalah klien dan memilih solusi intervensi yang tepat tidak lepas dari kemampuan perawat berfikir kritis untuk menggali berbagai alasan berdasarkan evidence base dari setiap problem dan solusi yang teridentifikasi (Potter \& Perry, 2010).

Salah satu penerapan pengambilan keputusan yang paling kritis dalam proses asuhan keperawatan adalah pada tahap perumusan diagnosa keperawatan, karena pada saat menentukan diagnosa, perawat harus menentukan dan menemukan masalah dalam menghadapi klien atau pasien dan diperlukan argumen secara rasional, sehingga masalah yang diangkat menjadi lebih jelas dan rasional.

Ada lima hal yang perlu diperhatikan dalam mengambil keputusan yaitu:

1. Dalam proses pengambilan keputusan yang diambil tidak terjadi secara berurutan.

2. Pengambilan keputusan tidak dilakukan secara tidak teratur tetapi harus berdasarkan sistematika tertentu, seperti: Tersedianya sumber-sumber untuk melaksanakan keputusan yang diambil, kualifikasi tenaga kerja yang akan diambil, kualifikasi tenaga kerja yang 
tersedia, falsafah yang dianut organisasi, situasi lingkungan internal dan eksternal yang akan mempengaruhi administrasi dan manajemen didalam organisasi.

3. Masalah yang diangkat harus diketahui dengan jelas.

4. Pemecahan masalah harus berdasarkan pada fakta-fakta yang terkumpul dengan sistematis.

5. Keputusan yang baik adalah keputusan yang telah dipilih dari berbagai alternative yang telah diajukan dan Dianalisa secara matang.

Perawat yang memiliki kemampuan keterampilan serta pengetahuan yang luas dalam pengambilan keputusan, maka akan dapat dengan mudah mengambil suatu keputusan terhadap masalah pasien untuk dapat menemukan solusi dalam mengatasi permasalahan kesehatan yang pasien alami melalui langkah-langkah proses pengambilan keputusan keperawatan.

Pengambilan keputusan yang baik akan meminimalisir bahaya yang terjadi terhadap pasien serta memiliki dampak yang positif terhadap perawatan yang dijalani pasien. Dengan perawatan yang berkualitas maka akan dapat meningkatkan mutu asuhan keperawatan dalam pelayanan kesehatan.

\section{Penutup}

Seorang perawat dalam menjalankan asuhan keperawatan dalam proses keperawatan wajib bisa mengambil keputusan dengan tepat. Pengambilan keputusan merupakan unsur penting dalam keperawatan karena berhubungan dengan asuhan keperawatan yang akan diberikan kepada pasien. Perawat memiliki tanggung jawab dan kewenangan untuk mengambil langkahlangkah keperawatan yang diperlukan sesuai dengan standar keperawatan dalam pengambilan keputusan khususnya.

Pengambilan keputusan adalah suatu proses penilaian dan pemilihan dari berbagai alternatif sesuai dengan kepentingan-kepentingan tertentu dengan menetapkan suatu pilihan yang dianggap paling menguntungkan. Pengambilan keputusan keperawatan dilakukan pada semua tahap proses keperawatan. Sehingga seorang perawat harus mampu berpikir ktitis, berkomunikasi dengan baik sebagai suatu elemen penting dalam pengaambilan keputusan klinis, sehingga terjadi pembelajaran berkelanjutan bagi pasien sehingga meningkatkan tingkat kemandirian pasien. 


\section{Daftar Pustaka}

Budiono. (2016). Konsep Dasar Keperawatan. Jakarta: Kementerian Kesehatan Republik Indonesia.

Candra Dewi Rahayu, S. M. (2020). PENGAMBILAN KEPUTUSAN KLINIS PERAWAT. Jurnal Ilmiah Kesehatan, 1-11.

Estik Ikka Indah Purwati, N. Y. (2017, Mei). Pengambilan Keputusan dalam Pelaksanaan Rujukan Puskesmas sebagai Fasilitas Kesehatan Tingkat Pertama. e-Jurnal Pustaka Kesehatan, 5(2), 231-238.

H, B. S. (2017, April). GAMBARAN KEMAMPUAN BERPIKIR KRITIS PERAWAT PRIMER DALAM PELAKSANAAN ASUHAN KEPERAWATAN DI RUMAH SAKIT ISLAM SURAKARTA. Jurnal Ilmu Keperawatan Indoensia, 10(1), 79-106.

Heni. (2017). Berfikir Kritis Dalam Proses Keperawatan. Jurnal Keperawatan. 3(1), 26-29

Ilfa Khairina, H. M. (2018, Maret). FAKTOR-FAKTOR YANG BERHUBUNGAN DENGAN PENGAMBILAN KEPUTUSAN PERAWAT DALAM KETEPATAN TRIASE DI KOTA PADANG. Indonesian Journal for Health Sciences, 2(1), 1-6.

Ilfa Khairina, H. M. (2020). PENGETAHUAN DAN KETERAMPILAN PERAWAT DALAM PENGAMBILAN KEPUTUSAN KLININ TRIASE. Jurnal LINK, 16(1), 1-5.

Kiki Deniati, R. A. (2018, Januari). PENGARUH BERFIKIR KRITIS TERHADAP KEMAMPUAN PERAWAT PELAKSANA DALAM MELAKUKAN ASUHAN KEPERAWATAN DI RUMAH SAKIT HERMINA BEKASI TAHUN 2016. Jurnal Kesehatan Holistik (The Journal of Holistic Healthcare), 12(1), 21-25.

Ose, M. I. (2017). Dilema Etik dalam Merawat Pasien Terlantar yang Menjelang Ajal di IGD. Jurnal Pendidikan Keperawatan Indonesia. Vol. 3(2). 145- 153.

Pashar, I. Dwiantoro, L. (2020). Pengaruh Empowerment Terhadap Pengambilan Keputusan Perawat: Kajian Literature Review. Journal of Holistic Nursing Science. Vol. 7(2). 124132. 
Simamora, R. H. (2019). Menjadi perawat yang: CIH'HUY. Surakarta: Kekata Publisher.

Simamora, R. H. (2005). Hubungan Persepsi Perawat Pelaksana Terhadap Penerapan Fungsi Pengorganisasian Yang Dilakukan Oleh Kepala Ruangan Dengan Kinerjanya Diruang Rawat Inap RSUD Koja Jakarta Utara (Doctoral dissertation, Tesis FIK UI, Tidak dipublikasikan).

Susi Erianti, R. M. (2019). Determinan Pengambilan Keputusan Klinik Keperawatan di RSUD Arifin Achmad Provinsi Riau. JURNAL KESEHATAN KOMUNITAS, 5(3), 227-234. 